\title{
Peningkatan Good Governance Melalui Penerapan Kaizen
}

\author{
Putri Nurmala*1, Akhmad Sigit Adiwibowo \\ Program Studi S1 Akuntansi, Fakultas Ekonomi, Universitas Pamulang, Tangerang Selatan \\ *Email:pnurmala@gmail.com
}

\begin{abstract}
Abstrak
Kaizen secara harfiah diartikan "Penyempurnaan". Pengertian tersebut memberikan makna yang luas terhadap penerapan Kaizen dalam kehidupan sehari-hari. Konsep Kaizen diartikan sebagai perbaikan terus-menerus dengan 5 (lima) pondasinya, yaitu aktivitas kelompok, kedisiplinan, pengembangan moral, kendali mutu, dan saran untuk perbaikan yang berasal dari semua pihak terkait. Melihat hal tersebut kami menimbang pentingnya Kaizen diterapkan di sekolah. Salah satu penerapan Kaizen adalah pembuatan laporan keuangan, yang mana di SDIT Al Inayah belum terdapat laporan keuangan. Hal ini tentu berdampak pada going concern dari sekolah tersebut. Metode pelaksanaan kami lakukan dengan survei terlebih dahulu terkait yang dibutuhkan oleh pihak SDIT Al Inayah. Ternyata apa yang dibutuhkan SDIT Al Inayah sejalan dengan tema PKM kami, yaitu pembuatan laporan keuangan. Setelah itu selama lima pekan setiap seminggu dua kali tim kami membantu membuat laporan keuangan Bulan Juli-September 2019 SDIT Al Inayah dengan menggunakan sistem aplikasi, yang mana sebelumnya masih manual di dalam beberapa buku. Hasil dari PKM ini adalah terwujudnya laporan keuangan SDIT Al Inayah dalam sistem aplikasi untuk Bulan Juli-September 2019. Selain itu pihak SDIT Al Inayah pun sekarang juga memahami pentingnya pembuatan laporan keuangan yang relevan dan akuntabel.
\end{abstract}

Kata Kunci--Good Governance, Kaizen, Laporan Keuangan

\begin{abstract}
Kaizen literally means "Improvement". This understanding gives broad meaning to the application of Kaizen in everyday life. The Kaizen concept is defined as continuous improvement with 5 (five) foundations, namely group activities, discipline, moral development, quality control, and suggestions for improvement that come from all relevant parties. Seeing this we consider the importance of Kaizen being applied in schools. One application of Kaizen is the preparation of financial reports, which in SDIT Al Inayah there are no financial reports. This certainly has an impact on the going concern of the school. The method of implementation was carried out with the first survey related to what was needed by the Al Inayah SDIT. It turns out that what is needed by SDIT Al Inayah is in line with our PKM theme, which is the preparation of financial reports. After that, for five weeks every week, twice, our team helped make financial reports in July-September 2019 SDIT Al Inayah by using an application system, which previously was still manual in several books. The result of this PKM is the realization of SDIT Al Inayah's financial reports in the application system for July-September 2019. In addition, SDIT Al Inayah now also understands the importance of making relevant and accountable financial statements.
\end{abstract}

Keywords--Good Governance, Kaizen, Financial Statements 


\section{PENDAHULUAN}

Pengabdian kepada masyarakat (PKM) dapat diartikan sebagai respon akademik masyarakat kampus atas kebutuhan, tantangan, atau persoalan yang dihadapi oleh masyarakat, baik secara langsung maupun tidak langsung. Berbekal kompetensi keilmuan yang dimiliki, kegiatan ini merupakan aktualisasi dari tanggungjawab dan kepedulian sosial warga kampus kepada masyarakat luas, yang meliputi usahausaha nyata untuk meningkatkan kualitas sumber daya manusia melalui perluasan wawasan dan pengetahuan, serta peningkatan keterampilan hidup. Terkandung di dalamnya partisipasi aktif, kreatif, dan inovatif warga kampus dalam berbagai bentuk community development yang bersifat transformatif, sehingga masyarakat mampu mencapai kehidupan yang lebih baik (mandiri dan bermartabat).

Akuntansi tidak hanya diartikan sekedar seperangkat alat untuk mencatat kejadian ekonomi, akan tetapi akuntansi mempunyai arti yang luas dan mempunyai suatu tujuan dalam setiap prosesnya. Perkembangan akuntansi sangat dipengaruhi oleh kebutuhan ekonomi dan teknologi, akuntansi akan selalu menciptakan suatu bahasa bisnis baru yang sesuai dengan kebutuhan ekonomi pada saat ini. Dalam setiap entitas ekonomi secara umum, akuntansi banyak memberikan kontribusinya dalam hal pengolahan sumber daya yang ada di dalam entitas tersebut, menciptakan kontrol internal, menguji akuntabilitas, dan lain sebagainya. Sehingga setiap entitas pasti akan membutuhkan adanya suatu proses akuntansi yang berjalan agar tujuan dari suatu entitas tersebut mampu diperhitungkan dan dicapai. Akuntansi tidak hanya berkelumit dalam entitas swasta saja akan tetapi akuntansi juga berlaku dalam sektor publik, seperti sekolah. Dalam 12 tahun terakhir terkenal adanya istilah Good Governance. Pengertian dari Good Governance adalah seperangkat proses yang diberlakukan dalam organisasi baik swasta maupun negeri untuk menentukan keputusan.

Salah satu cara meningkatkan good governance adalah dengan menerapkan Kaizen. Kaizen sendiri secara harfiah diartikan "Penyempurnaan". Pengertian tersebut memberikan makna yang luas terhadap penerapan Kaizen dalam kehidupan sehari-hari. Kaizen adalah filosofi kerja yang diturunkan dari hasil sistem pendidikan dan interaksi sosial budaya Jepang yang mengutamakan keharmonisan dan kegiatan bersama. Dampak langsung dari Kaizen adalah produk Jepang yang mencirikan, yang disempurnakan secara berkesinambungan sehingga produk makin lama makin baik kualitasnya dan makin murah harganya. Konsep Kaizen diartikan sebagai perbaikan terusmenerus dengan 5 (lima) pondasinya, yaitu aktivitas kelompok, kedisiplinan, pengembangan moral, kendali mutu dan saran untuk perbaikan yang berasal dari semua pihak terkait. Prinsip Kaizen yang tercermin dari elemen kuncinya yaitu kualitas, usaha, keterlibatan semua pihak, kemauan untuk berubah dan komunikasi yang dilaksanakan melalui siklus PDCA (Plan, Do, Check, Act) dan SDCA (Standardize, Do, Check, Act) (Imai, 1996 : 216).

Melihat hal tersebut kami menimbang pentingnya Kaizen diterapkan di sekolah. Salah satu penerapan Kaizen adalah pembuatan laporan keuangan, yang mana di SDIT Al Inayah belum terdapat laporan keuangan. Hal ini tentu berdampak pada going concern dari sekolah tersebut. 


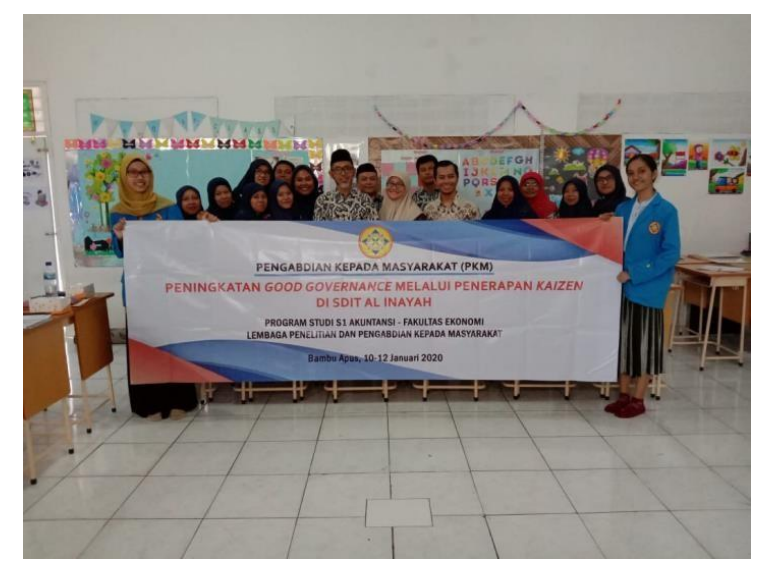

Gambar 1. Tim Dosen PKM Unpam, mahasiswa Unpam, dan guru beserta staff SDIT Al Inayah Bambu Apus

Berdasarkan latar belakang tersebut, kami dari Tim Pengabdian Kepada Masyarakat (PKM) Universitas Pamulang (Unpam) yang berjumlah dua dosen dan dua mahasiswa terpanggil untuk ikut serta membantu SDIT Al Inayah dengan judul PKM: "Peningkatan Good Governance Melalui Penerapan Kaizen".

\section{METODE PELAKSANAAN}

Hal mendasar yang ditawarkan dalam PKM ini untuk memecahkan masalah adalah melalui kegiatan membantu pembuatan laporan keuangan dan pemahaman pentingnya laporan keuangan untuk keberlangsungan (going concern) SDIT Al Inayah kepada guru dan TU SDIT Al Inayah yang dikemas dengan nama kegiatan PKM "Peningkatan Good Governance Melalui Penerapan Kaizen".

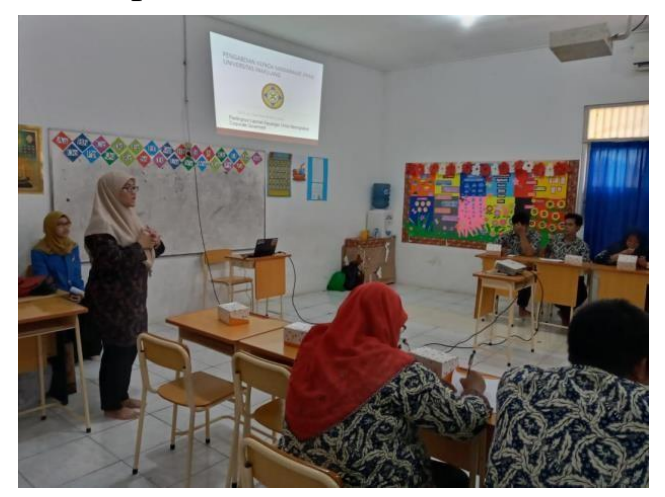

Gambar 2. Proses Penyampaian Materi dari

\section{Tim Pemateri PKM}

Metode pelaksanaan yang kami rencanakan untuk PKM ini, yaitu:

1. Kami melakukan survei terlebih dahulu, survei ini untuk mengetahui lokasi, pihak pihak terkait, kondisi yang ada di SDIT Al Inayah, permasalahan, dan sebagainya.

2. Setelah itu kami melakukan analisis SWOT dari hasil survei yang sudah kami lakukan di SDIT Al Inayah. Hal ini dilakukan untuk mengerti dengan luas mengenai SDIT Al Inayah, sehingga kami tidak salah sasaran.

3. Berikutnya kami menghubungi pihak SDIT lagi untuk mengajukan PKM ini yang berupa penyuluhan dan nantinya pendampingan untuk mengetahui kesiapan dari pihak SDIT Al Inayah.

4. Setelah mereka konfirmasi mengenai waktu dan pihak yang akan menghadiri, kami pun membuat perencanaan dan timeline acara, serta persiapan materi.

5. Lalu hari pelaksanaan PKM. Saat pelaksanaan kami akan memberikan materi dan diskusi. Di sini kami akan sangat terbuka terkait pertanyaanpertanyaan dari pihak SDIT Al Inayah.

6. Setelah pelaksanaan PKM itu kami menerima kritik dan saran dari pihak SDIT Al Inayah berupa kuesioner yang berisi instrumen pertanyaan.

7. Selanjutnya kami akan memantau secara berkala atau pendampingan mengenai pembuatan laporan keuangan di SDIT Al Inayah selema beberapa bulan. 


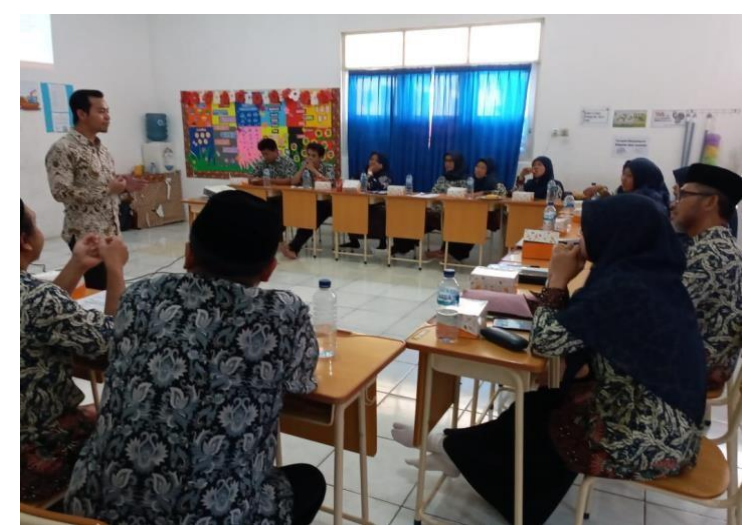

Gambar 3. Peserta Mendengarkan pemaparan materi

Sasaran program PKM yang akan dituju adalah guru dan TU SDIT Al Inayah di Bambu Apus, Pamulang Sejumlah 17 peserta. Jumlah ini bisa berubah tergantung dari pihak SDIT Al Inayah. Prosedur yang akan digunakan dalam PKM ini adalah melalui kegiatan:

1. Pelatihan, pelatihan akan dilakukan pada hari $\mathrm{H}$ pelaksanaan PKM. Kami akan menjadi narasumber mengenai materi Laporan Keuangan. Dan pelatihan ini bersifat diskusi.

2. Praktik materi, setelah materi kami akan langsung uji coba praktiknya. Hal ini untuk menyamakan pemahaman dari peserta.

3. Rancangan Evaluasi, Evaluasi kegiatan dilakukan setelah kegiatan penyuluhan dan pelatihan kepada guru dan TU SDIT AL Inayah yaitu dengan cara mengisi instrumen yang disiapkan oleh TIM PKM terkait bagaimanakah tanggapan guru dan TU SDIT Al Inayah terhadap kegiatan PKM yang dilakukan oleh Tim Dosen Akuntansi Universitas Pamulang. Nantinya pun kami akan melihat tolak ukur keberhasilan penerapan Kaizen ini melalui laporan keuangan sebelum PKM ini dan setelah PKM dilaksanakan.

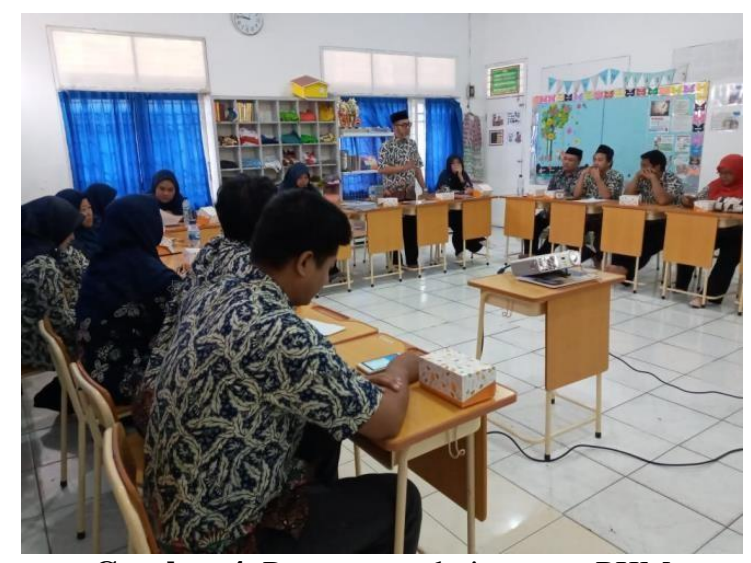

Gambar 4. Pertanyaan dari peserta PKM

\section{HASIL DAN PEMBAHASAN}

Dari hasil observasi kami, laporan keuangan SDIT AL-Inayah masih kurang relevan dan akuntabel dikarenakan masih menggunakan manual yang ditulis dalam buku tulis. Bentuknya pun bukan laporan keuangan, hanya catatan pengeluaran dan pemasukan saja. Selain itu, masih kurang memiliki kesadaran terkait Sistem Pengendalian Internal. Pihak SDIT Al Inayah pun belum memahami pentingnya laporan keuangan bagi keberlangsungan (going concern) SDIT Al Inayah.

Pentingnya Laporan Keuangan Untuk Meningkatkan Corporate Goverment

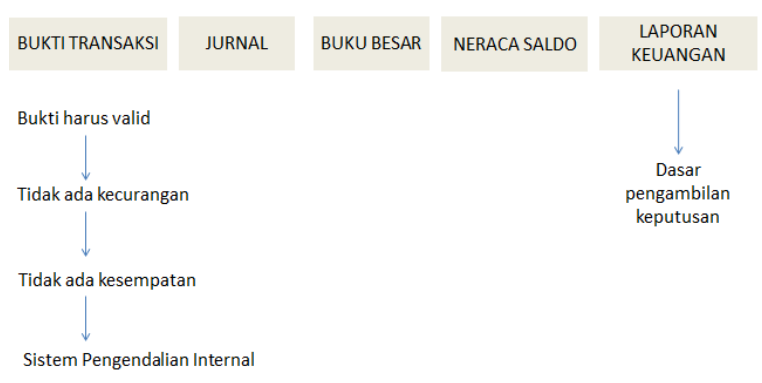

Gambar 5. Pentingnya Laporan Keuangan untuk Meningkatkan Corporate Governance

Contoh Sistem Pengendaian Internal Yang Baik untuk Kas dan Setara Kas:

- Seharusnya: Semua penerimaan dan pengeluaran kas harus melalui bank.

- Actual: Belum terjadi. Peneriman Kas masih dengan metode langsung/manual (cash on hand)

- Dampak: Dikhawatirkan atau 
berpeluang terjadinya kesalahan baik yang disengaja baik tidak disengaja.

- Rekomendasi: Disarankan menggunakan rekening bank sebagai alat bantu penerimaan dan pengeluaran kas. Dengan bantuan rekening bank, pemanfaatan waktu lebih efisien. Untuk pengeluaran dengan nominal kecil disarankan untuk membuat akun kas kecil dengan metode impress fund system. (menetapkan jumlah/saldo pasti yang tetap untuk pengeluaran per bulan).

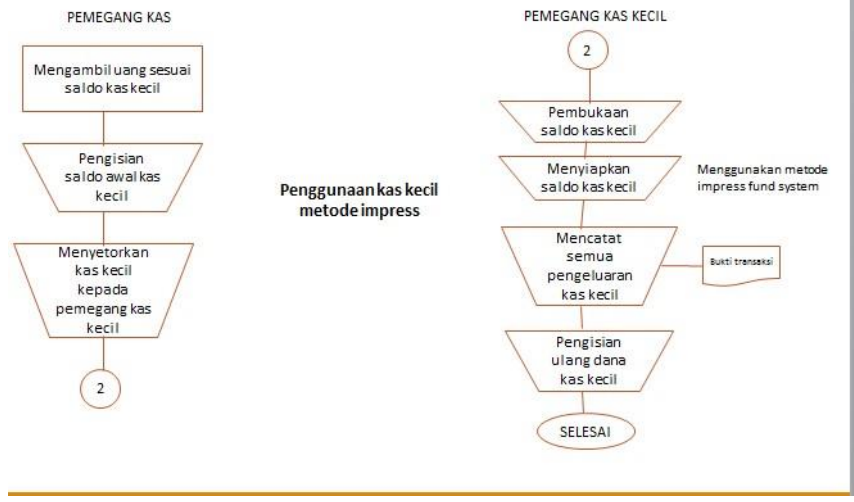

Gambar 8. Sistematika Penerimaan dan Pengeluaran Kas Metode Pembayaran Manual Lanjutan

Sistematika penerimaan dan pengeluaran kas

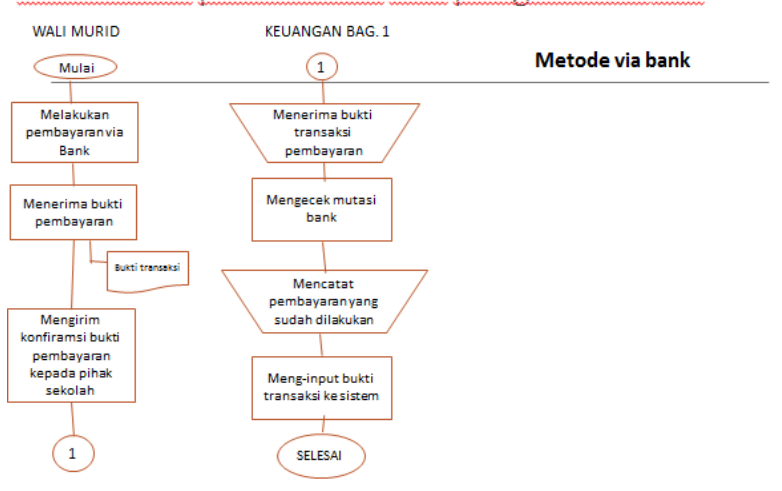

Gambar 6. Sistematika Penerimaan dan Pengeluaran Kas Metode Via Bank

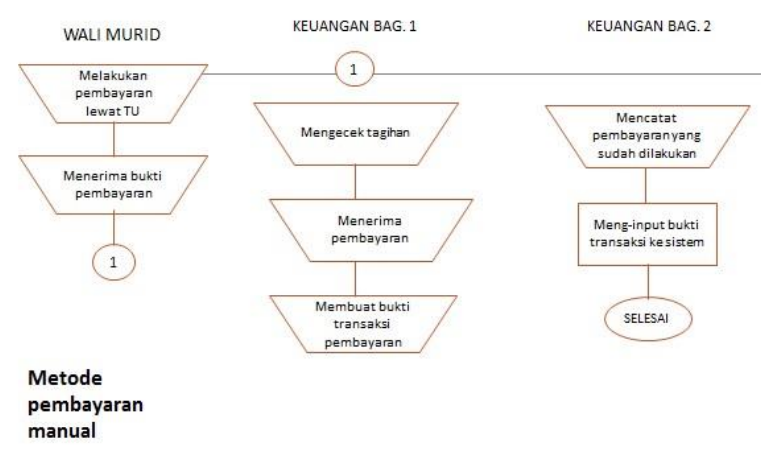

Terlampir laporan keuangan SDIT Al Inayah Bulan Juli-September 2019 yang kami buat dalam sistem aplikasi:

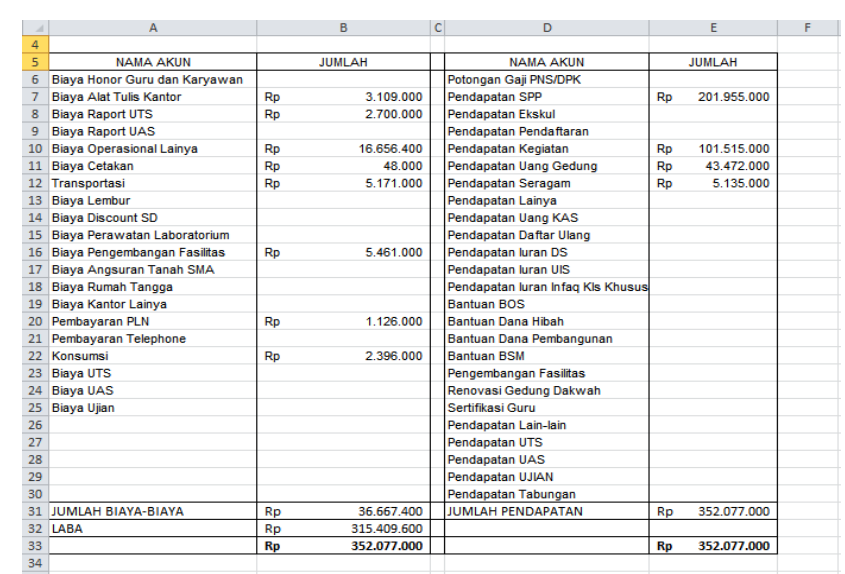

Gambar 9. Laporan Laba Rugi SDIT Al Inayah Juli-September 2019

Dari Laporan Laba Rugi yanng sudah kami buat dalam sistem aplikasi sudah dapat terlihat pemasukan dan beban-beban

Gambar 7. Sistematika Penerimaan dan Pengeluaran Kas Metode Pembayaran Manual 
yang dikeluarkan SDIT Al Inayah, namun masih terdapat data yang kurang yaitu mengenai beban gaji staf dan guru dikarenakan kami belum mendapatkan datanya. Tetapi laporan laba rugi tersebut sudah cukup representatif sebagai laporan keuangan dibandingkan sebelumnya dimana pengeluaran dan pemasukan masih ditulis manual di dalam buku.

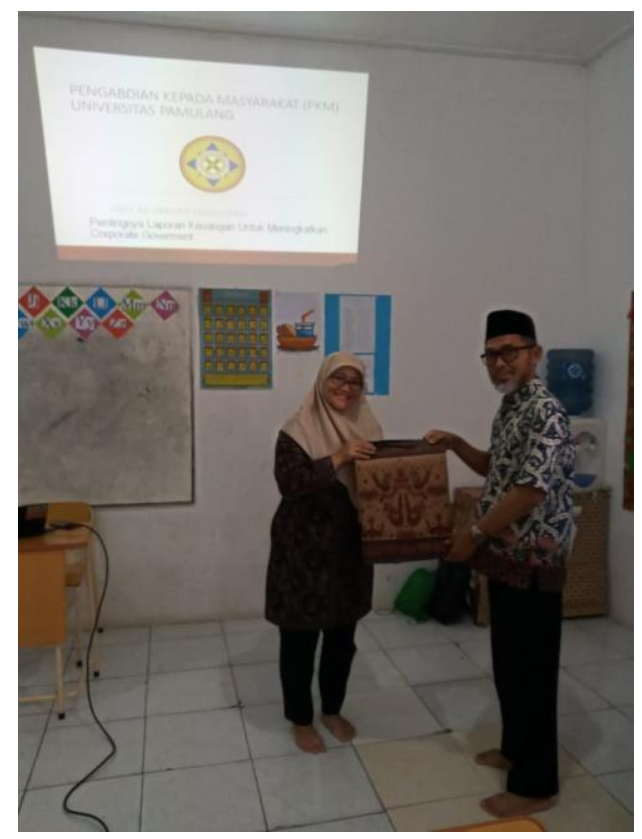

Gambar 10. Pemberian Cinderamata dari Tim PKM kepada Kepala Sekolah SDIT Al Inayah

\section{DAFTAR PUSTAKA}

Dwiyanto, Agus. 2009. Mewujudkan Good Governance Melalui Pelayanan Publik. Yogyakarta : Gajah Mada Univercity Press.

Imai, Masaaki. 1994. KAIZEN (Ky'zen). Kunci Sukses Jepang Dalam Persaingan. Jakarta Pusat: PT Pustaka Binaman Pressindo.

Imai, Masaaki. 1996. Gemba Kaizen. Jakarta Pusat: PT Pustaka Binaman Pressindo. Imai, Masaaki. 2008. The Kaizen Power. Yogyakarta:

\section{KESIMPULAN}

Berdasarkan kegiatan PKM yang telah dilaksanakan dapat ditarik beberapa kesimpulan antara lain sebagai berikut:

1. Sebelum adanya PKM, laporan keuangan SDIT Al Inayah masih kurang relevan dan akuntabel dikarenakan masih manual. Namun, setelah PKM sudah terdapat laporan keuangan JuliSeptember 2019 dalam sistem aplikasi dan bisa dilanjutkan.

2. Pihak SDIT Al Inayah belum memahami pentingnya laporan keuangan untuk keberlangsungan (going concern) SDIT Al Inayah. Namun, setelah PKM pihak SDIT Al Inayah mulai memahami pentingnya laporan keuangan bagi SDIT Al Inayah.

\section{UCAPAN TERIMAKASIH}

Ucapan terimakasih penulis ucapkan kepada Lembaga Penelitian dan Pengabdian Masyarakat (LPPM) Unpam yang telah memberikan bantuan dana pengabdian kepada PKM ini. Peneliti juga mengucapkan terimakasih kepada SDIT Al Inayah sebagai tempat PKM kami.

Think.

SMK Farmasi Nasional Surakarta. 2018. PENERAPAN 5R (RINGKAS, RAPI, RESIK, RAWAT, RAJIN). Melalui link http://www.smkfarmasinasional.sc h.id/post-penerapan- 5r-ringkasrapi-resik-rawat-rajin.html. Diakses 23 Oktober 2019.

SMP Cendekia Baznas. 2019. 5R, Bentuk Karakter Siswa yang Cinta Kebersihan. Melalui link 
https://www.cendekiabaznas.sch.i d/5r-bentuk-karakter-siswa-yangcinta- kebersihan/. Diakses 23 Oktober 2019

Yenny. 2013. Prinsip-prinsip Good Governance. Jurnal Fisip Unmul
Vol.1 p.3. Melalui link http://ejournal.an.fisipunmul.ac.id/site/wpcontent/uploads/2013/03/EJOURN AL\%20YENNY\%20(03-02-1306-48-29.pdf. Diakses 23 Oktober 2019. 